University of Louisville

ThinkIR: The University of Louisville's Institutional Repository

\title{
Goodnight moonshine : the lasting effects of prohibition on the
} United States.

John Slack

University of Louisville

Follow this and additional works at: https://ir.library.louisville.edu/honors

Part of the United States History Commons

\section{Recommended Citation}

Slack, John, "Goodnight moonshine : the lasting effects of prohibition on the United States." (2015). College of Arts \& Sciences Senior Honors Theses. Paper 34.

http://doi.org/10.18297/honors/34

This Senior Honors Thesis is brought to you for free and open access by the College of Arts \& Sciences at ThinkIR: The University of Louisville's Institutional Repository. It has been accepted for inclusion in College of Arts \& Sciences Senior Honors Theses by an authorized administrator of ThinkIR: The University of Louisville's Institutional Repository. This title appears here courtesy of the author, who has retained all other copyrights. For more information, please contact thinkir@louisville.edu. 


\section{Goodnight Moonshine:}

The Lasting Effects of Prohibition on the United States

By

John Slack

Submitted in partial fulfillment of the requirements

for graduation (summa or magna) cum laude

and

for Graduation with Honors from the Department of History

University of Louisville

May, 2015 


\section{Introduction}

Alcohol constitutes an integral part of societies across the world. This pattern can be seen in the United States where conflicts over alcohol's place in the country have permeated the social landscape since the beginning of the nation. From colonial times to the modern day, society has viewed alcohol as a deplorable vice, an enjoyable indulgence, a rite of passage, an inherent freedom, and the reason for many of society's woes. To better understand alcohol's role in United States history, one needs to examine a key event and public policy that dealt with alcohol: Prohibition. Spanning from 1920 to 1933, historians have identified Prohibition as a well-meaning effort by temperance groups to regulate drinking in America. However, Prohibition failed due to the expansive nature of the law and the resistance by many citizens to this legislation. As a result, President Franklin Roosevelt's administration discarded it as a failed experiment. However, like many historical topics, the truth is more complex and deserves to be analyzed in-depth. This analysis can be done by exploring the process that led to the passage of the Eighteenth Amendment and the 1920 Volstead Act, and why they failed. Nonetheless, despite the relative shortness of Prohibition, its effect on American society was substantial such as innovations in tactics for special interest groups, a shift in the cultural significance of drinking, and adding to the discussion of the federal and state governments' role in the citizens' lives. This essay demonstrates that, in some ways, Prohibition failed in its short term goals and partially succeeded in the long run.

\section{Historiography of Prohibition}

To better understand Prohibition, one needs to analyze how the topic has been studied over the years. Even when Prohibition was in effect writers commented on the legislation, such as scholar Henry Joy who stated in 1925 that "Many have come to think and believe that after the 
most diligent effort for five years by the Government of the United States of America to enforce bone dry Prohibition upon our people, it has totally failed." ${ }^{1}$ Since then many scholars have concluded that Prohibition created more problems than it remedied and regarded the experiment as an overall failure. ${ }^{2}$ Historian Thomas D. Clark states that this failure was because enforcement of Prohibition proved impossible and "instead of checking completely the manufacture of liquor, the amendment encouraged moonshining and bootlegging.”3 ${ }^{\text {This }}$ interpretation is taught in most classrooms across the nation, and has become the dominating viewpoint in the historical field. However, this viewpoint is not the only interpretation as some scholars in recent years have begun to argue that Prohibition may have been more successful than previously thought. Historian Bartlett Jones argues that Prohibition helped the economy of the United States by increasing "the purchasing power of the entire nation. In other words, it was held that liquor purchases were less desirable, for the entire economy, than the purchase of durable consumer goods." ${ }^{4}$ Historians such as John Burnham maintain that the dramatic decrease in liquor psychoses cases illustrate the success of Prohibition. ${ }^{5}$ Other scholars maintain that Prohibition also succeeded by killing off the saloon and that the need for tax revenue during the Great Depression, and not popular sentiment, led to the amendment's repeal. ${ }^{6}$ However, many historians still point to the repeal of the Eighteenth Amendment and the survival of alcohol in society today as proof that Prohibition was a well-meaning experiment that was too idealistic

\footnotetext{
${ }^{1}$ Henry Bourne Joy, “Prohibition against Human Nature,” The North American Review 221, no. 827 (1925): 609.

${ }^{2}$ George Blakely, Hard Times \& New Deal in Kentucky, 1929-1939 (Lexington, Kentucky: University Press of Kentucky, 1986), 142.

${ }^{3}$ Ibid.,145.

${ }^{4}$ Bartlett C. Jones, “Prohibition and Prosperity, 1920-1930,” Social Science 50, no. 2 (1975): 79. ${ }^{5}$ John C. Burnham, "New Perspectives on the Prohibition 'Experiment' of the 1920's," Journal of Social History 2, no. 1 (1968): 60.

${ }^{6}$ Ibid., 67.
} 
to ever succeed. While this debate illustrates that the field is far from reaching a consensus, one important idea to remember is that issues such as Prohibition are complex and require information from different perspectives to understand the situation. To understand this topic, one needs to understand how temperance originated in the United States and why these activists sought to purge alcohol from the country.

\section{Background}

Temperance has existed in the United States since the creation of the original thirteen colonies. According to historian Michael Thornton, the growth of Prohibition can be organized into three phases, the first of which is considered the birth of Prohibition and spanned from colonial times to the early 1800 s. $^{7}$ However, most people who participated in this early movement did not advocate for a complete prohibition of alcohol; rather they sought to restrict the drinking of alcohol from groups such as Native Americans and slaves. ${ }^{8}$ Others such as Doctor Benjamin Rush advocated that all citizens should moderate their alcohol intake, as many people during this time period drank at every social event and while working. ${ }^{9}$ Meanwhile, the federal government began to recognize the potential revenue alcohol manufacturing could produce for the country. Government officials began to implement protectionist legislation to encourage alcohol production causing some areas to produce over 1,000,000 gallons of rum annually during the early eighteenth century. ${ }^{10}$ After this first period, the second phase of the temperance movement began with the Second Great Awakening which began in 1790 and

\footnotetext{
${ }^{7}$ Michael Thornton, The Economics of Prohibition (Salt Lake City: University of Utah Press, 1991), 40. ${ }^{8}$ Ibid., 41.

${ }^{9}$ Richard Hamm, Shaping the Eighteenth Amendment: Temperance Reform, Legal Culture, and the Polity, 1880-1920 (Chapel Hill: University of North Carolina Press, 1995), 19-20.

${ }^{10}$ Thornton, Economics of Prohibition, 42.
} 
changed the perception of liquor to a vice and an evil that destroyed individuals and their families. ${ }^{11}$ As this religious revival began to influence many citizens living in rural areas, notable temperance groups formed to spread this policy across the nation. A key aspect of these groups was the desire to educate others on the dangers of drinking such as the case with the Washingtonians in the 1840s who sought to teach others of their experiences with drinking and promote moderation for drinkers. ${ }^{12}$ However, a radical section in this wave of temperance movements began to gain power and influence temperance politics and arguments.

As the 1800s progressed and industrialization and the Civil War changed the United States these changes also affected alcohol's place in society and the movement that sought to control it. Temperance groups, such as the Women’s Christian Temperance Union (WCTU) and National Prohibition Party, launched an all-out attack on the liquor trade. This attack consisted of citing alcohol as the reason for domestic violence in working class families and for the degradation of living conditions in the newly industrialized cities marking the transition to historian Michael Thornton's third phase of Prohibition. ${ }^{13}$ For some Prohibitionists alcohol was the reason for many of the world's problems. As activist Richard Hobson stated, "War, anarchy, and unrest will disappear with the advent of a dry universe."14 Due to these movements drinking became centralized in saloons and, by 1873, 100,000 saloons existed across the nation. By 1890, cities with a population over 50,000 had a saloon for every 250 inhabitants. ${ }^{15}$ The saloon also became a symbol for Catholicism during this time, as some Protestants saw the

\footnotetext{
${ }^{11}$ Hamm, Shaping Eighteenth Amendment, 20.

12 Thornton, Economics of Prohibition, 43.

13 Ibid., 48.

14 “Dry World is Due Soon, says Hobson,” Courier-Journal (Louisville, K.Y.), April 17, 1920, 12.

${ }^{15}$ Hamm, Shaping Eighteenth Amendment, 22.
} 
saloon as a meeting place for Catholics during a time of hostility toward that religion. Many Protestants saw the saloon as an institution that needed to be destroyed and realized that they needed the political clout to eliminate this institution. To accomplish this goal the Prohibition Party and others groups became associated with other public reforms such as reforms on child labor, an income tax, and direct election of senators in order to gain support from other groups and citizens. ${ }^{16}$ This increase in political prominence can be seen with statistics on the Prohibition Party, as they rose from 0.05 percent of the vote in the presidential election of 1872 to 2.25 percent in $1892 .{ }^{17}$ The Party's rise in political power led many government officials to understand that this issue would soon become a national one and they began to readjust their view on public issues. However, many thought that these prohibitionist groups were too radical in nature due to their absolutist philosophy and only supported them due to their advocacy of Protestant beliefs. ${ }^{18}$ The use of these Protestant values became central to many Prohibitionists as the Union Signal, a prohibitionist newspaper, reported "The evil is a national evil, the sin of perpetuating it is a national sin; God deals with nations as nations, and accepts no expiation for that nation's sin.”19 This absolutist philosophy led Prohibitionist leaders to seek a legal way to end the liquor trade on a national scale and for some this goal meant the creation of a national prohibition amendment.

\section{Conflict between Wet and Dry Forces}

As the Prohibitionist groups gained power, the leaders of the movement realized that national legislation would be needed to enact the type of dry utopia they envisioned. Many

\footnotetext{
${ }^{16}$ George Yater, Two Hundred Years at the Falls of the Ohio: A History of Louisville and Jefferson County (Louisville: Heritage Corporation, 1979), 148.

${ }^{17}$ Thornton, Economics of Prohibition, 49.

${ }^{18}$ Hamm, Shaping Eighteenth Amendment, 25-26.

${ }^{19}$ Ibid., 8.
} 
leaders in these groups realized that they needed a total prohibition of alcohol if they were to save the nation from the vice of alcohol. While these dry groups had success on the local level (through the implementation of local option laws and a license system to regulate who could sell alcohol in dry areas) many reasoned that these local policies would not be enough and began to attack any measure that did not strive for total prohibition of alcohol. ${ }^{20}$ This ideology can be seen in the primary source, the Cyclopedia of Temperance, Prohibition, and Public Morals, in which temperance leaders pointed out, "Local option grew up as a kind of natural fungus upon the license system stock."21 However, different factors impeded their efforts to enact national Prohibition. For one, a rising immigrant population caused many politicians, especially in the Democratic Party, to hesitate endorsing Prohibition legislature on the chance that it may affect their chances of reelection. ${ }^{22}$ Another was the special relationship that many brewers and distillers shared with the federal government due to the lucrative revenue the industry brought the federal government. This special relationship existed from 1873-1917 when the national government levied heavy taxes on alcohol and this increase ended up accounting for 23 percent of the nation's tax receipts. ${ }^{23}$ Likewise, after the Civil War, the federal government relied on the liquor industry for funds to help with reconstruction efforts and due to this reliance on alcohol tax revenue, taxes on alcohol generated 20-41 percent of the nation's tax revenues from 18731916. ${ }^{24}$ Distillers and brewers used this close relationship to the national government to promote this image of patriotism for the industry which hurt efforts to institute Prohibition. ${ }^{25}$

\footnotetext{
${ }^{20}$ Ibid.,28.

${ }^{21}$ Deets Pickett, Clarence Wilson, and Ernest Smith, Cyclopedia of Temperance, Prohibition, and Public Morals, (New York: Methodist Book Concern, 1917), 390.

${ }^{22}$ Hamm, Shaping Eighteenth Amendment, 30.

${ }^{23}$ Ibid., 46.

${ }^{24}$ Ibid., 94-95.

25 Ibid., 96.
} 
Prohibitionists responded to this propaganda by stating that the federal tax "has made the infernal business appear as one of the pillars of the country, when it is nothing more than a caterpillar living upon the fruits of others' industry."26 However, attempts to repeal this tax led to dissension in the dry groups as more moderate members advocated for the tax as a way to control and restrict the trade. ${ }^{27}$ This dissension and the lucrative nature of the liquor trade caused many groups, such as the Women’s Christian Union and the Prohibition Party, to collapse in the 1890s and created a leadership vacuum to emerge in the dry movement. Ideas that ran contrary to the Prohibitionists' absolutist plans began to appear, including the Swedish Gothenburg plan that called for the federal government to take over the saloon industry and other plans that proposed nationalizing the liquor industry in order to better control the trade. ${ }^{28}$ A new organization would be needed to lead the various dry groups and pave the way for national Prohibition—a group that would approach the situation more subtly and pragmatically than their predecessors.

Enter the Anti-Saloon League (ASL), founded in 1893 by Howard Hyde Russell, which focused on agitation of the public, government legislation, and legal enforcement to enact their plan. ${ }^{29}$ To carry out this plan the League focused on local measures and initiatives to educate the public and enforce local measures that went unenforced by local agencies. To educate citizens the League created the Lincoln Legion to educate the youth of the nation about temperance and began employing lawyers, such as Wayne Wheeler, to force local police agencies to enforce local anti-liquor laws. Legal culture became important to the League and, by 1908, they had participated in over 31,000 cases of liquor law enforcement. To ensure these rulings were

\footnotetext{
${ }^{26}$ Ibid., 2.

${ }^{27}$ Ibid.,101-102.

${ }^{28}$ Ibid., 128.

${ }^{29}$ Ibid., 132.
} 
carried out, the ASL began enlisting volunteers, private detectives, and government officials to see to the enforcement of these laws. ${ }^{30}$ As the League became more and more familiar with legal proceedings many in the organization began to see the potential to utilize the existing government structure to restrict and curtail the liquor trade. Namely dry forces realized that Congress could restrict liquor transport under the Commerce Clause in the Constitution. In order to strengthen their argument that Congress should step in and regulate the liquor trade, dry forces cited the then recently passed the 1912 Mann Act, which banned interstate transport of prostitutes under the logic that Congress had the power to ban items that were harmful to others and to commerce. Under this reasoning, dry forces pushed for the passage of the Webb-Kenyon Act in 1913, which made it illegal to ship alcohol to dry states and would leave penalties up to the state to decide. ${ }^{31}$ Wet forces fought back, however, and claimed that any bill that would make the transport of alcohol illegal violated the freedom of commerce, granted extraterritoriality to state laws, and delegated Congress's power to regulate commerce to state governments. ${ }^{32}$ However, wet forces faced disunity in the ranks due to the competitive nature of the liquor market. Due to this disunity the Webb-Kenyon Act passed and allowed states to issue new regulations for interstate trade. The new legislation soon caused some transport agencies like the Rock Island Railroad to report that liquor transports had fallen by 80 percent. ${ }^{33}$ Pressure from dry groups caused states to pass bone dry laws to prohibit all alcohol and, by 1917, eighteen states instituted these laws. While the League had made great progress to achieving national prohibition, it required one more event to facilitate their dream.

\footnotetext{
${ }^{30}$ Ibid., 132-142.

${ }^{31}$ S.J. Mennell, “Prohibition: A Sociological View,” Journal of American Studies 3, no. 2 (1969): 161.

32 Hamm, Shaping Eighteenth Amendment, 208.

${ }^{33}$ Ibid., 220-236.
} 


\section{Final Push for Prohibition}

As different acts of legislation threatened to end the alcohol trade, Europe contended with the onset of World War I. While the United States had managed to remain outside of the war, by 1917, many came to believe that the United States would need to enter the war. In order to prepare for this entrance into the war, Congress began to draft different bills and laws to supply the troops deploying to Europe to fight Germany and the Austro-Hungarian Empire. The Food Control Bill of 1917 aimed to control and ration foodstuffs in order to feed the troops; but, one particular section of the bill caused an uproar with wet forces. This section was the Albert Cummins Amendment, which prohibited the manufacture of whiskey because the distilling process used grains and other foodstuffs. ${ }^{34}$ Across the nation wet forces scrambled to fight this amendment and prevent its passage by explaining the disastrous effects it would have on the economy. Thomas M. Gilmore, president of the Model License League, predicted that the amendment would mean "frightful bankruptcy [of distilleries] all over the country."35 He predicted that in Louisville, Kentucky, alone 5-6 million dollars worth of warehouse receipts would be lost. ${ }^{36}$ Others such as Owsley Brown, vice-president of the Brown-Foreman Company, estimated that based on the previous fiscal year Kentucky would lose $\$ 1,300,000$ in taxes per year and the federal government stood to lose $\$ 33,000,000$ a year. ${ }^{37}$ Other experts from across the nation began to protest the measure as well, with some predicting that the Senate would need one billion dollars to cover the deficit it would create. ${ }^{38}$ Despite these dire predictions, however, Congress passed the amendment and distilling became illegal giving many in the dry movement

\footnotetext{
34 “On Food Control Bill,” Courier-Journal, July 7, 1917, 1.

35 Ibid., 1.

${ }^{36}$ Ibid., 1.

${ }^{37}$ Ibid., 1.

38 “Senate Action brings Flood of Protests,” Courier-Journal, July 8, 1917, 1.
} 
reason to believe that a national amendment to outlaw alcohol was near. In a vote of sixty-five to twenty the Senate passed the Morris Sheppard Resolution which called for the House to vote "upon a constitutional amendment for nation-wide prohibition."39 Due to the successes of such measures and the lack of clear leadership in the wet forces, the debate in the Senate became onesided and the ASL invoked allusions to the moral crusade against slavery in order to sway Senators to vote to destroy, what they perceived as, this evil subversive vice in the nation. ${ }^{40}$ On December 17, 1917, the amendment passed the House 282-126 and passed through the Senate the next day with a vote of $47-8 .{ }^{41}$ States began to ratify the amendment in order to ratify Prohibition and by March 1918 twenty-six of the necessary thirty-eight states needed for a majority had ratified the measure. ${ }^{42}$ On January 16, 1918, Nebraska became the thirty-eighth state to ratify the amendment thus adding the amendment to the 1787 Constitution. ${ }^{43}$ While a national Prohibition code would need to be worked out, the ASL and other dry forces had succeeded in bringing about national Prohibition. This success, though, would be short-lived as its goals of complete prohibition would be too lofty ever to be met.

\section{Implementation of Prohibition}

While the ASL had succeeded in passing Prohibition, the task of implementing and enforcing it now stood before the organization. To accomplish this task, the ASL needed a national Prohibition code to enforce the act before Congress enacted the Amendment. Hence the creation of the Volstead Act, which sought to encapsulate many of the state dry laws that had been enacted before the Eighteenth Amendment; this also sought to be a model of speed and

\footnotetext{
39 "Prohibition Wins Victory in Senate; Vote is 65 to 20," New York Times, August 2, 1917, 1.

${ }^{40}$ Hamm, Shaping Eighteenth Amendment, 244.

${ }^{41}$ Ibid., 247.

42 "Predict Dry Nation Within A Year," New York Times, March 11, 1918, 4.

${ }^{43}$ Hamm, Shaping Eighteenth Amendment, 248.
} 
efficiency. Congress divided the Volstead Act into three sections, the first of which implemented wartime bans on alcohol in order to ensure that the country did not turn wet inbetween the expiration of the former bans and the enactment of Prohibition. ${ }^{44}$ The next section encapsulated the national Prohibition code that outlawed the manufacture, sale, transport, and possession of liquor except for the fermentation of fruit juices at home, which was deemed the apple cider exception. ${ }^{45}$ The third and final section then dealt with the production of alcohol for industrial use and the regulations needed to ensure it was not made for personal use. ${ }^{46}$ To ensure this provision the Act called for strict regulation of businesses and industries that would still deal with alcohol legally. These people included Church officials, druggists, doctors, and manufacturers and to reinforce these regulation powers. The Volstead Act provided government officials the power to search any vehicles or buildings involved in the liquor trade. ${ }^{47}$ While the inclusion of these powers did create some controversy, the most controversial issue in the Act was the classification of intoxicating liquors, which set the alcohol level at one-half of one percent by volume. This standard meant that beer and other light alcoholic beverages became illegal as well. ${ }^{48}$ Despite this definition the Act passed Congress and went to President Woodrow Wilson for approval. However, Wilson was not an ardent supporter of Prohibition and vetoed the bill on the grounds that the wartime bans on alcohol made the Volstead Act redundant. ${ }^{49}$ Congress overrode this veto and began to make arrangements to carry out the Volstead Act on a national scale. While some states fought this provision, the federal courts

\footnotetext{
${ }^{44}$ Ibid., 251.

${ }^{45}$ Ibid., 251.

${ }^{46}$ Ibid., 251.

${ }^{47}$ Ibid., 252.

${ }^{48}$ Ibid., 252.

${ }^{49}$ Ibid., 252.
} 
upheld the classification and ensured that national Prohibition could continue as planned. This ruling, along with the enforcement of the Volstead Act, constituted a victory for the ASL and the other dry forces, but other interest groups would soon arise to undermine all of their hard work.

\section{The Reality of Prohibition}

Despite the many victories the ASL had achieved over its existence, the actual implementation of Prohibition proved to be the undoing of its dream. At the beginning of Prohibition's implementation the Volstead Act seemed to be working as alcohol was difficult to obtain and purchase. ${ }^{50}$ In fact statistics on the gallons of alcohol consumed per capita illustrate this decrease in alcohol consumption, going from .97 gallons in 1918-1919 to .73 gallons from 1921-1922. ${ }^{51}$ The most compelling evidence may be found in the decrease of alcohol psychoses. In May 1922, psychiatrist James May, "With the advent of prohibition the alcoholic psychoses as far as this country is concerned have become a matter of little more than historical interest. The admission rate in New York state hospitals for 1920 was only 1.9 percent [as compared with ten percent in 1909-1912]. ${ }^{\text {52 }}$ However, inherent weaknesses in the Volstead Act soon buried these early success stories. One of these weaknesses involved the way in which the state and federal governments shared the enforcement power, with a majority of the enforcement burden falling on state and local governments. Unfortunately for the ASL many states failed to enforce this legislation and this lack of enforcement led to a breakdown of national Prohibition across the nation. In some areas not enough police and court and prison resources existed to enforce the Eighteenth Amendment, such as in Chicago, Illinois where the federal government tasked 100

\footnotetext{
50 Burnham, “New Perspectives,” 58.

51 Ibid., 59.

52 James V. May, Mental Diseases, A Public Health Problem, (Boston: R.G. Badger Co., 1922), 360-362.
} 
federal officials to police millions of citizens on these new laws. ${ }^{53}$ Other states such as New Jersey refused to enforce the Eighteenth Amendment and made no effort to enforce the Volstead Act. ${ }^{54}$ This outlawing of alcohol also caused a spike in crime in urban cities such as Chicago and Louisville which created an environment that allowed bootleggers and gangsters to thrive. For Louisville in particular, a thriving underground market formed for alcohol with some police precincts reporting as many as eighty-three raids in one week to root out bootleggers. ${ }^{55}$ Police officers in these raids reported "stills in private homes, watered whiskey at newsstands, bottled beer, moonshine, and expensive liquor" all over the city. ${ }^{56}$ Even prestigious locations such as the Pendennis Club participated in these illegal activities as early as 1922, with one officer declaring, "I never saw so many different kinds of drinks in my life." ${ }^{\text {. }}$ Some citizens also claimed that one could arrange to buy whiskey privately, with one person recalling how he would go to the Watterson Hotel and rendezvous with the bell-captain to buy "a pint of Old Sunnybrook for seven dollars. ${ }^{58}$ This environment that tolerated low-level crime soon caused a public backlash against Prohibition that signaled the beginning of the end for the Eighteenth Amendment.

As Prohibition began to degrade, the public soon turned against the legislation for a variety of reasons. All across the nation different groups and organizations opposed the Volstead Act in an effort to kill the bill. In some cities local enforcement agents refused to enforce the Act due to their disagreement with its principals, such as in Chicago in 1929 where out of 126

\footnotetext{
${ }^{53}$ Scott Schaeffer, "The Legislative Rise and Populist Fall of the Eighteenth Amendment: Chicago and the Failure of Prohibition,” The Journal of Law \& Politics, 26 (2011): 389.

54 Burnham, "New Perspectives," 58.

${ }^{55}$ Yater, Falls of the Ohio, 173.

${ }^{56}$ Ibid., 173.

${ }^{57}$ Ibid., 189.

58 Ibid., 189.
} 
bootleggers in the city only one was arrested and received a small fine and sentence. ${ }^{59}$ An example of this can also be seen in other cities, such as in Louisville where Judge Evans and United States Attorney B. M. Russell agreed to return a local bootlegger's stash of whiskey and gin after he paid a $\$ 100$ fine because the amount of alcohol "was not enough to justify forfeiture to the government.” ${ }^{\circledR 0}$ This resistance to the Eighteenth Amendment by local enforcement agents can be attributed to many different factors. As the 1920s progressed, public opinion on Prohibition soured as many observed the rise in crime and bootlegging as proof that the Volstead Act had failed. This viewpoint was prominent in many industrialized cities, such as in Chicago in the early 1920s when 391,280 citizens voted against the Eighteenth Amendment as compared to 144,032 that voted in favor of the bill. ${ }^{11}$ In Chicago especially, this backlash was not only caused by economic reasons but also by cultural differences, as many immigrant groups vehemently opposed the legislation. In fact, many of the infamous mobsters in Chicago were immigrants, as thirty percent of the criminal leaders in the city were Italian and twenty-nine percent were Irish. ${ }^{62}$ This gap between the public and the federal government caused tensions to form between local and federal agents. Despite the fact the national government bestowed many powers to dry enforcement agents, such as the ability to "hold court, examine physicians regarding issuance of whiskey prescriptions, and decide on revocation of permits,” many agents found it almost impossible to fulfill their duties due to interference from local policing agencies. ${ }^{63}$ This conflict with local law enforcement increased with time, with many dry agents

${ }^{59}$ Schaeffer, "Populist Rise and Fall," 404-405.

60 “Owner Fined \$100, Gets Seized Liquor,” Courier-Journal, April 1, 1920, 12.

61 Schaeffer, "Populist Rise and Fall," 401.

62 Ibid., 403-404.

63 “Right of Dry Agents to Void Permits up Today,” Courier-Journal, April 2, 1921, 5. 
quitting due to claims of being hounded and framed by local police officers. ${ }^{64}$ Combined with the loss of many people's jobs in alcohol related industries, including a loss of 6,000-8,000 jobs in Louisville, Kentucky alone, these factors only served to increase this public backlash against the Eighteenth Amendment. ${ }^{65}$ As historian George Blakely points out, the loss of jobs caused “an industry-wide depression nine years before the Great Crash.”66 However, one more event would precipitate the end of the Prohibition experiment.

\section{The Great Crash}

Despite the increasing difficulties with Prohibition, many in the federal government clung to the hope that the experiment would succeed and prove the naysayers wrong. For a time, the booming economy and prosperity of the 1920s helped to offset the lost jobs and allowed the experiment to continue. However, this changed in 1929 when the stock market crash and the Great Depression ushered in a decade of joblessness and poverty. Across the nation unemployment skyrocketed and the population suffered, with federal censuses reporting nine percent of the nation's citizens were unemployed. ${ }^{67}$ Many citizens began to support the end of Prohibition as the 1920s drew to a close with a poll for Literary Digest reporting that 73,000 Kentuckians agreed that Prohibition was a failure. ${ }^{68}$ As the backlash against Prohibition increased, many politicians and government officials switched sides in the dry vs. wet debate, such as Kentucky's Alben Barkley who abandoned the dry crusade in the early 1930s due to the fact that Prohibition "was neither working nor popular." 69 Others in the federal government also

\footnotetext{
64 “Another Agent Quits Dry Post in Lexington, KY,” Courier-Journal, July 3, 1926, 1.

65 Yater, Falls of the Ohio, 173.

66 Blakely, Hard Times, 144.

${ }^{67}$ Yater, Falls of the Ohio, 195.

68 Blakely, Hard Times, 146.

${ }^{69}$ Ibid., 146.
} 
began to acknowledge Prohibition’s failure, including President Hoover’s Wickersham

Commission which stated in 1931 that "prohibition had become an expensive failure."70 The Democrats decided to latch onto this sentiment and promised to repeal the Eighteenth Amendment as part of their 1932 platform. ${ }^{71}$ This platform and the nation's desire for change helped to usher in Franklin D. Roosevelt to victory in the 1932 election, but this change did not signal a definitive end to the Volstead Act. Gradual steps needed to be taken in order to kill the legislation and repeal the Eighteenth Amendment for good. The first step meant liberalizing the Volstead Act by legalizing the sale of beer and light wines. ${ }^{72}$ The changes to the act allowed breweries to make beer with an alcoholic content of 3.2 percent and led to cities such as Louisville to begin "issuing beer licenses again after a thirteen year lapse."73 While this change in policy proved to be a very important step, Prohibition of hard liquor remained in effect and many citizens and officials began the final push to repeal the Volstead Act. Beginning in February of 1933, Congress began making plans to repeal the Eighteenth Amendment and end Prohibition. ${ }^{74}$ Different states convened to ratify the measure and by December 5, 1933, the Twenty-First Amendment passed and marked an official end to the Eighteenth Amendment and Prohibition.

\section{Effects of Prohibition}

For many historians, Prohibition seems to be a failure that was doomed to fail due to its idealistic nature and lack of broad public support. Many politicians at the time welcomed the

\footnotetext{
${ }^{70}$ Ibid., 146.

${ }^{71}$ Yater, Falls of the Ohio, 195.

72 Blakely, Hard Times, 146.

${ }^{73}$ Yater, Falls of the Ohio, 195.

${ }^{74}$ Michael Munger and Thomas Schaller, "The Prohibition-Repeal Amendments: A Natural Experiment in Interest Group Influence,” Public Choice 90, no. 1/4 (1997): 141.
} 
repeal of the Eighteenth Amendment due to the new jobs it brought in and the return of a profitable industry for the federal government. However, to ignore the long-term effects this legislation had on the United States is irresponsible. Take for example, the effect the temperance movements had on special interest group tactics and mobilization. In their effort to enact national Prohibition, many dry advocates utilized the state and federal courts and new lobbying techniques to enact legislative change. This shift in ideology can be seen in the ASL, which created organizations such as the Lincoln Legion to educate the youth on the positive effects of temperance and to promote the creation of new laws to restrict liquor sales. ${ }^{75}$ The ASL's focus on local option laws also shows their dedication to utilizing the legal framework of the United States to enact change. ${ }^{76}$ The League also employed lawyers such as Wayne Wheeler to litigate cases in order to ensure that local option laws were upheld. This approach resulted in over 31,000 cases being tried by $1908 .^{77}$ Similar tactics have been used by other groups since that time in order to effect change in the United States. Organizations such as the National Association for the Advancement of Colored People (NAACP) and civil rights unions have funded clients in court cases in order to encourage social change through the judicial system much like the temperance movement did in cases like the National Prohibition Cases in $1920 .^{78}$ Further, the temperance movement continued a precedent that had started with the abolitionist movement and that trend was the inclusion of women in social movements. During the early 1900s women fought to gain more political powers and influence in the public sphere. While women were involved in the abolitionist movement of the early to middle 1800s, they did

\footnotetext{
${ }^{75}$ Hamm, Shaping Eighteenth Amendment, 132.

76 Ibid., 133.

77 Ibid., 141.

78 Ibid., 250.
} 
not gain their true footing in social movements until the temperance movement. The creation of organizations such as the Women's Christian Temperance Union and the growth of such social reform groups illustrated this shift from the private sphere of home life to the public sphere of politics and social policy. This rapid growth can be seen in the fact that by 1908 the WCTU had established offices in every state and territory in the United States and in over 10,000 localities. ${ }^{79}$ While many men opposed this cultural shift, women of the time used the dominant ideology of women to their advantage to join the discussion on alcohol. This dominant ideology included a belief that women should only be concerned with matters relating to the home and family. Women used this cultural value to justify their place in the public sphere by reasoning that drunken husbands posed a danger to the family. ${ }^{80}$ Many women would use this ideology and the corruption of the political system to rationalize the passing of suffrage for women in order to promote morality in the political sphere. Suffragists later used tactics they had learned from the temperance movement to promote suffrage and help pass the Nineteenth Amendment. The success of the suffrage movement and temperance organizations such as the WCTU illustrated the value of women in similar social movements and shifted the demographics of such groups to include new members such as women. All of these factors combine to demonstrate that the temperance movement changed how social movements and special interest groups operated in the United States. However, to fully appreciate the effects of Prohibition and the temperance movement one needs to analyze the movement had on drinking itself.

Today many citizens view alcohol as a vice that is best enjoyed in moderation and for special occasions or events. This view, however, was not as common in the early 1900s as

${ }^{79}$ Lillian Stevens, "The Work of the National Woman's Christian Temperance Union,” Annals of the American Academy of Political and Social Science 32 (1908): 38.

${ }^{80}$ Thornton, Economics of Prohibition, 48. 
drinking was much more common in everyday life than it is today. Immigration and assimilation were partly to blame for this practice as many immigrants from Europe viewed liquor as a daily part of their meals and socialization and even had their children drink as a part of this cultural practice. As the famous social worker Jane Addams experienced, many immigrants would feed their children wine-soaked bread as breakfast for their children before sending them off for the day ${ }^{81}$ Examples like this story demonstrates the view many held on alcohol at the time; that it was a harmless indulgence and did no major damage to people. For many, alcohol was also used for medicinal purposes to cure various ailments and this understanding caused doctors to prescribe whiskey for treatment for some ailment. ${ }^{82}$ This ideology changed though with the rise of the temperance movement as groups began to educate the citizenry on the dangers of alcoholism, such as the Lincoln Legion in the early 1900s that sought to teach youth about the dangers of liquor and the benefits of temperance. ${ }^{83}$ Also, advances in medical knowledge such as new insights in germ theory diminished the medicinal uses of alcohol. While Prohibition may have failed to rid the United States of alcohol, the proliferation of this information about alcohol's harmful effects on the human body did help to lower alcohol consumption. In fact, this decline can be observed during 1830 and 1840, a time when temperance movements began to disseminate this knowledge of alcohol's effects. During this time period the amount of alcohol consumed per capita dropped from 9.5 to 5.5. ${ }^{84}$ While enforcement of Prohibition caused consumption fluctuations, many sources agree that alcohol consumption decreased during this

\footnotetext{
${ }^{81}$ Jane Addams, Twenty Years at Hull-House, (New York: MacMillan Company, 1912), 102103.

82 Blakely, Hard Times, 144.

${ }^{83}$ Hamm, Shaping Eighteenth Amendment, 132.

${ }^{84}$ Harry G. Levine and Craig Reinarman, "From Prohibition to Regulation: Lessons from Alcohol Policy for Drug Policy,” The Milbank Quarterly 69, no. 3 (1991): 468.
} 
time period. From 1911-1914 the amount of gallons of pure alcohol consumed by person was 1.69 gallons, which decreased under wartime restrictions on alcohol during 1918-1919 to .97 gallons and then to .73 gallons during the first years of Prohibition from 1921-1922. ${ }^{85}$ These consumption levels would not reach pre-Prohibition levels again until the 1970s thus demonstrating the long-term effects of this legislation. ${ }^{86}$

Another major consequence of Prohibition was a shift in the brewing industry itself. After the Civil War, local breweries sprang up across the nation as a wave of immigration and a high demand for alcohol after the war allowed the industry to expand. By 1910 the brewing industry had become one of the largest manufacturing sectors in the United States. ${ }^{87}$ However, due to the enforcement nature of Prohibition, prohibition policies caused many small local breweries to close down while some larger breweries adapted, gained licenses to produce alcohol for industrial purposes, or produced other goods like cereal beverages. ${ }^{88}$ The influence of temperance and Prohibition caused the number of breweries to decline sharply from 1,847 breweries across the nation to 1,345 by $1915 .^{89}$ These numbers continued to plummet as Prohibition caused many of these local breweries to close down. This shift in production ensured a dependence on large brewing corporations rather than locally owned breweries. This change in the brewing landscape demonstrates how Prohibition not only affected the United States on a political level but also on an economic level as well. However, the most noticeable change the

\footnotetext{
${ }^{85}$ Burnham, "New Perspectives," 59.

${ }^{86}$ Richard Chin, “Prohibition Worked, say some Historians. Could it Come Back?,” Saint Paul Pioneer Press, (1997): 1.

${ }^{87}$ Martin Stack, “Local and Regional Breweries in America's Brewing Industry, 1865 to 1920,” The Business History Review 74, no. 3 (2000): 448.

${ }^{88}$ Yater, Falls of the Ohio, 174.

89 Stack, "Local Breweries," 449.
} 
temperance movement and Prohibition brought about may deal with a modern day issue that faces controversy.

The increased awareness of how the negative effects of alcohol has caused the federal government to reevaluate how best to handle alcohol production, distribution, and consumption. Due to the disastrous nature of shared enforcement between federal and state governments during Prohibition, states have been responsible for much of the legislation regarding alcohol and restrictions on liquor since 1933. As scholar Sarah Liebschutz points out, "Statutes and regulations concerning age of purchase, possession and consumption of alcoholic beverages, definitions of drinking while impaired or intoxicated, penalties for drunk driving, and dram shop laws as well as enforcement of all of these matters [are] regarded as exclusive prerogatives of the states." 90 The basis for this power originated from the efforts of temperance groups before and during Prohibition as several groups such as the ASL focused on local measures and ordinances to promote temperance. In fact many states still utilize local options laws to determine if alcohol will be sold in counties. Despite the time that has passed, these measures have been effective in lowering alcohol consumption and alcohol related accidents while driving and across the culture. $^{91}$

However, changes in the nation including a rise in technology and transportation have forced the state and federal governments to reevaluate how drinking is handled. The major change in the United States in this regard since Prohibition has been the rise in automobiles and drunk driving across the nation. This correlation can be seen with statistics from 1996 that

${ }^{90}$ Sarah F. Liebschutz, “The National Minimum Drinking-Age Law,” Publius 15, no.3 (1985): 40.

${ }^{91}$ Robert W. Brown and R. Todd Jewell, "County-Level Alcohol Availability and Cirrhosis Mortality,” Eastern Economic Journal 22, no.3 (1996): 291. 
illustrate how alcohol abuse has been linked to 20,000 cases of fatal motor vehicle accidents annually. ${ }^{92}$ In order to compensate for this rise in drunk driving, many state governments have revived and renewed tactics common during the Progressive Era. These tactics include excise taxes on liquor which raised the price of alcohol and, in that fashion, have reduced alcohol consumption and heavy drinking. ${ }^{93}$ Different local organizations formed to push for education on drinking and the dangers of driving while intoxicated such as Mothers Against Drunk Driving (MADD) and Remove the Intoxicated Driver (RID). ${ }^{94}$ Still, these new temperance groups faced a similar problem of disorganization with these education and enforcement measures and the states lacked uniformity with many of these ordinances. The most significant measure undertaken to standardize many of these laws was the 1984 passage by Congress of a minimum drinking age law. ${ }^{95}$ The 1984 National Minimum Drinking-Age Act declared that the national age required for purchasing and possessing alcohol was twenty-one years old and sought to restrict alcohol consumption and increase penalties for driving while intoxicated. ${ }^{96}$ While controversy exists over the drinking age and whether it should be lowered, various social studies indicate that the law does lower alcohol related driving accidents. ${ }^{97}$ All of these factors have come together as a continuation of temperance ideology and succeeded in one of the Prohibitionist's goals of restricting alcohol to minors. In fact, some scholars have called the passage of these measures and this proliferation of knowledge on alcohol's negative effects as proof that the United States has entered into a neo-temperance era. ${ }^{98}$ The persistence in utilizing

\footnotetext{
${ }^{92}$ Ibid., 291.

${ }^{93}$ Ibid., 291.

${ }^{94}$ Liebschutz, "Drinking Age Law,” 41.

${ }^{95}$ Ibid., $42-43$.

${ }^{96}$ Ibid., 41.

${ }^{97}$ Chin, "Prohibition Worked," 1.

${ }^{98}$ Ibid., 1.
} 
local organizations and ordinances indicates Prohibition's lasting effect on the United States. But, the most important legacy of Prohibition is on the United States federal government itself.

To pass the Eighteenth Amendment and ratify Prohibition, the ASL and other temperance groups needed to engage and change the legal culture of the United States. This shift resulted in new interpretations of the Constitution and the powers of Congress and the national government. One crucial shift was the belief that Congress has the power to regulate enterprises that are harmful to citizens or the morality of the nation—a concept known as the federal police power. The passage of acts such as the 1912 Mann Act to restrict interstate transportation of women engaged in prostitution and the 1920 Volstead Act to enforce Prohibition embodied this nationalizing concept of a federal police power. ${ }^{99}$ These acts also established the precedent for how Congress regulated interstate commerce. According to decisions such as Leisy v Hardin (1890), the Supreme Court of the United States decided that Congress had jurisdiction over interstate commerce and established how Congress could relegate this power to the state governments. ${ }^{100}$ These precedents came back into play with the passage of various acts regarding the interstate alcohol trade. The most significant act in recent history would be the passage of the 1984 National Drinking Age Act. ${ }^{101}$ While deliberations over the constitutionality of this bill progressed, various committees concluded that the rulings that the liquor trade was interstate, the interstate nature of highways, and the power to protect the safety of citizens justified the legislation. ${ }^{102}$ However, the end of Prohibition also had an effect on discussions regarding the regulation of the liquor trade across state lines. Namely the Twenty-First

\footnotetext{
${ }^{99}$ Hamm, Shaping Eighteenth Amendment, 225.

100 Ibid., 187.

101 Liebschutz, “Drinking Age Law,” 45.

102 Ibid., 45.
} 
Amendment which ended Prohibition and stipulated that any laws that prohibit the transport of liquor into states are voided. ${ }^{103}$ The Twenty-First Amendment and these other acts contribute to the legal culture of the United States and the powers of the federal government over the lives of American citizens. However, discussions on issues such as the power of the state and federal governments in vice control and regulation of morality are ones that continues to dominate political discussion in the United States today. One of these discussions includes the legalization of marijuana for medicinal and even recreational use. To better understand this debate, many have drawn parallels between alcohol and drug prohibition. For instance, both attempts to regulate vices encouraged many small-scale entrepreneurs to start selling drugs or alcohol to make a profit. ${ }^{104}$ Many scholars suggest that if the United States government instituted a system to regulate drug use like the system and coupled it with social services and employment for the inner-city population, one would be able to see decreases in drug abuse. ${ }^{105}$ While drug regulation would be more complex than alcohol regulation due to the many types of drugs available, the possibility still exists for such a system. The increasing legalization of drugs such as marijuana that have medicinal purposes poses an interesting dilemma for the United States government that is not dissimilar to the situation the federal government faced in the 1920s.

\section{Conclusion}

While some historians may see Prohibition as a noble experiment that failed to achieve its goals the historical reality and significance are more complicated. Prohibition was an idealistic effort to rid the United States of a vice that threatened to undo the moral fiber of the nation and a vice that caused many of the societal problems that persisted in the early 1900s. The social

\footnotetext{
103 Ibid., 46.

${ }^{104}$ Levine and Reinarman, "Drug Policy,” 472.

105 Ibid., 483.
} 
reform attempted to do much in a too short amount of time and failed to anticipate the resistance the Eighteenth Amendment would face on the state level as well as the public's backlash against the legislation. Coupled with the Great Depression and the need to supply jobs to the citizenry, Congress discarded the Eighteenth Amendment for practical reasons. While some historians have argued that Prohibition was a failure that left no major mark on United States history, one can see how the ideas of Prohibition and temperance have survived to the present day and have continued to affect national legislation. Whether it is the passage of the 1984 Minimum Drinking Age Law or the continued emphasis on educating citizens on the harmful effects of alcohol consumption, the ideas of temperance continue to permeate discussions on the issue. Prohibition also continues to be a key part of debates on how the government should handle regulation on drugs and other vices, such as the legalization of marijuana and the effectiveness of the War on Drugs. So while Prohibition may have failed to abolish alcohol completely from the United States the long-term effects of these ideas continue to limit the consumption of alcohol and influence how citizens view, consume, and tolerate alcohol. In some ways Prohibition's more realistic goals of limiting alcohol's place in society succeeded and helped to usher in a new era of understanding alcohol and its benefits and problems. Those ideas will continue to evolve and affect how vices such as alcohol is used in ordinary people's lives and might one day help create the perfect (or at least better) world the Prohibitionists envisioned for the future. 
Bibliography

\section{Secondary Sources}

Blakely, George. Hard Times \& New Deal in Kentucky, 1929-1939. Lexington, Kentucky: University Press of Kentucky, 1986.

Brown, Robert W., and R. Todd Jewell. "County-Level Alcohol Availability and Cirrhosis Mortality.” Eastern Economic Journal 22, no.3 (1996): 291-301.

Burnham, John C. "New Perspectives on the Prohibition 'Experiment' of the 1920's.” Journal of Social History 2, no. 1 (1968): 51-68.

Chin, Richard. “Prohibition Worked, say some Historians. Could it Come Back?.” Saint Paul Pioneer Press, (1997): 1.

Hamm, Richard. Shaping the Eighteenth Amendment: Temperance Reform, Legal Culture, and the Polity, 1880-1920. Chaplin Hill: University of North Carolina Press, 1995.

Jones, Bartlett C. “Prohibition and Prosperity, 1920-1930.” Social Science 50, no. 2 (1975): 7886. 
Levine, Harry G., and Craig Reinarman. "From Prohibition to Regulation: Lessons from Alcohol Policy for Drug Policy.” The Milbank Quarterly 69, no. 3, (1991): 461-494

Liebschutz, Sarah F. “The National Minimum Drinking-Age Law.” Publius 15, no.3 (1985): 3951.

Mennell, S.J. “Prohibition: A Sociological View.” Journal of American Studies 3, no. 2 (1969): 159-175.

Munger, Michael, and Thomas Schaller. "The Prohibition-Repeal Amendments: A Natural Experiment in Interest Group Influence.” Public Choice 90, no. 1/4 (1997): 139-163.

Schaeffer, Scott. "The Legislative Rise and Populist Fall of the Eighteenth Amendment: Chicago and the Failure of Prohibition.” The Journal of Law \& Politics, 26, (2011): 387-424.

Stack, Martin. "Local and Regional Breweries in America's Brewing Industry, 1865 to 1920.” The Business History Review 74, no. 3 (2000): 435-463.

Thornton, Michael. The Economics of Prohibition. Salt Lake City: University of Utah Press, 1991.

Yater, George. Two Hundred Years at the Falls of the Ohio: A History of Louisville and Jefferson County. Louisville: Heritage Corporation, 1979.

\section{Primary Sources}

Addams, Jane. Twenty Years at Hull-House. New York: MacMillan Company, 1912.

“Another Agent Quits Dry Post in Lexington, KY.” Courier-Journal. July 3, 1926.

"Dry World is Due Soon, says Hobson.” Courier-Journal. April 17, 1920.

Joy, Henry Bourne. “Prohibition against Human Nature.” The North American Review 221, no. 827 (1925): 608-611.

“On Food Control Bill.” Courier-Journal. July 7, 1917.

“Owner Fined \$100, Gets Seized Liquor.” Courier-Journal. April 1, 1920.

May, James V. Mental Diseases. A Public Health Problem. Boston: R.G. Badger Co., 1922. 
Pickett, Deets, Clarence Wilson, and Ernest Smith. Cyclopedia of Temperance, Prohibition, and Public Morals. New York: Methodist Book Concern, 1917.

“Predict Dry Nation Within A Year.” New York Times. March 11, 1918.

“Prohibition Wins Victory in Senate; Vote is 65 to 20.” New York Times. August 2, 1917.

“Right of Dry Agents to Void Permits up Today.” Courier-Journal. April 2, 1921.

“Senate Action brings Flood of Protests.” Courier-Journal. July 8, 1917.

Stevens, Lillian. "The Work of the National Woman's Christian Temperance Union.” Annals of the American Academy of Political and Social Science 32, (1908): 38-42. 